\title{
Profile of Triiodothyronine (T3) and Thyroxine (T4) of female Bali breed cattle transported by traditional vessel from Sumbawa to Pontianak
}

\author{
Nichlah Rifqiyah ${ }^{1,2 *}$, Hindar Panguji ${ }^{2}$, Irkham Widiyono ${ }^{3}$, and \\ Pudji Astuti ${ }^{3}$ \\ 1Faculty of Veterinary Science, Universitas Gadjah Mada, Yogyakarta, Indonesia \\ 2Quarantine Medical Veterinarian Kendari Agricultural Quarantine Agency, Puuwatu, \\ Kendari, Southeast Sulawesi, Indonesia \\ 3Faculty of Veterinary Medicine, Universitas Gadjah Mada, Yogyakarta, Indonesia \\ *e-mail: drh.nichlah@gmail.com
}

\begin{abstract}
Transportation of livestock using traditional vessel is one of traditional method used to fulfill the needs of beef. It requires precise handling because it may cause stress in animals. Transportation stress causing 8 to $11 \%$ of animal death, decreasing the body weight up to $8 \%$ and decreasing reproductive performance of animals. This study aimed to determine the profile of triiodothyronine (T3) and thyroxine (T4) hormones in 1 to 2 y.o female Bali breeding cattle transported from Sumbawa to Pontianak for $120 \mathrm{~h}$ using $100 \mathrm{GT}$ traditional vessel with two floors and a capacity of 300 to 400 heads. Five cows were selected by purposive sampling. Blood samples were taken three times: before transportation (at Sumbawa Animal Quarantine Installation), during loading (at traditional vessel) and after transportation (at Pontianak Animal Quarantine Installation) then tested by ELISA to determine the profile of triiodothyronine (T3) and thyroxine (T4). The result showed that there was a decline in triiodothyronine (T3) and thyroxine (T4) concentration, they increased during loading, decreased during docking, and decreased further when the livestock were at Animal Quarantine Installation. Therefore, transportation affects the profile of triiodothyronine (T3) and thyroxine (T4). It would be concluded that transportation affected hormone of $\mathrm{T} 3$ and $\mathrm{T} 4$.
\end{abstract}

\section{Keywords}

thyroxine (T4), traditional vessel, transportation, triiodothyronine (T3), Bali breed cattle

Citation: Rifqiyah, N., Panguji, H., Widiyono, I., Astuti, P.: Profile of Triiodothyronine (T3) and Thyroxine (T4) of female Bali breed cattle transported by traditional Vessel from Sumbawa to Pontianak. In: I.W. Mustika, I. Kartini. (eds.): Proceeding of the 3rd International Conference on Science and Technology, Vol. 1, pp. 31-38. UGM Digital Press Physical Science and Engineering, Yogyakarta (2018).

Published: October, 2018

\section{Introduction}

Bali cows (Bossondaicus) are the beef cows of Indonesian indigenous breeds as the result of domestication of bull (Bosbibos). Bali cows, also known as Balinese cows, are greatly potential supply meat to fulfill the protein needs of Indonesian people [1]. Great demand of the Balinese cows in certain areas in Indonesia results in the increase of sea traffic from an island to another. The cattle transportation from the port of Sumbawa to the port of Pontianak takes approximately $120 \mathrm{~h}$. During the sea transportation, the cattle need the careful handling because the condition of the ship, density of cattle, weather or climate changes and 
food availability can cause stress on the cattle. It was reported that there was a significant risk for the cattle welfare caused by transporting the animal in the ships, especially for a long distances. The long-distance transportation of cattle involves changes in animal feeding, density, and social grouping, climate, and stall when compared with their previous habitats, often being shepherded on the rangeland [2].

The improper handling of transportation results in the cattle depression and stress. The transportation stress cause around $8 \%$ to $11 \%$ of the death [3], $8 \%$ body shrink [4], and reduces reproductive performance of animal [5,6]. Stress can affect the secretion of the thyroid hormone namely triiodothyronine (T3) and tetraiodothyronine / thyroxine (T4) with various mechanisms [7,8]. Stress induces the increased activity of the hypothalamic-pituitary-thyroid axis together with peripheral tissue [9] which causes changes in secretion of T3 and T4 by thyroid gland. The thyroid hormone effects the carbohydrates metabolism in some mechanisms, one of which by increasing the absorption of glucose in the intestine. The intestine facilitates the movement of glucose into fat and muscle [10].

To avoid bad effects of the transportation on the cattle welfare, the management transportation before, during, and after transportation must be taken into account. There have been no standard international regulations for the cattle transportation through the sea [11], but the guidelines for the cattle welfare carried by the ship have been developed by the International Air Transport Association (IATA) and The World Organization of Animal Health (OIE) in 2003-2004 and the inserted into the OIE Terrestrial Animal Health Code [12]. The guidelines explain minimum animal welfare and health standards during pretransportation, loading, transportation, unloading, and handling stages after the sea transportation [13].

This research was aimed to investigated profile of T3 and T4 hormones of Balinese female cows transported for $120 \mathrm{~h}$ using traditional vessels. The research on the hormone profile of T3 and T4 on Bali female cows transported for $120 \mathrm{~h}$ using traditional vessel from Sumbawa to Pontianak has never been done before.

\section{Methods}

All methods of this study were approved by Ethics Commission of the Integrated Research and Testing Laboratory, Universitas Gadjah Mada (LPPT UGM), under no.00096/04/LPPT/XI/2016.

\subsection{Materials}

Five Balinese female cows aged 1 to 2 y.o were selected by purposive sampling, transported from Sumbawa to Pontianak for $120 \mathrm{~h}$ using $100 \mathrm{GT}$ traditional vessel with two floors with capacity of 300-400 heads. All cattle were given the green feed and drinking water ad libitum and placed in the upper floor.

\subsection{Research Design}

The blood sampling was performed in three times: before transportation (at Sumbawa Animal Quarantine Installation), during loading (at traditional vessel) and after transportation (at Pontianak Animal Quarantine Installation)

\subsection{Sampling and Blood Analysis}

\subsubsection{Preparation Phase}

Balinese female cow were adapted for $19 \mathrm{~d}$ in the Quarantine Installation of Agricultural Quarantine Sumbawa before the animals were transported by sea. During the adaptation period, the measurement of body temperature was performed. Each of the cow was kept in $4.8 \mathrm{~m}^{2} \cdot \mathrm{pen}^{-1}$. The cows were placed head to head in a row and given green feed and drinking water ad libitum.

\subsubsection{The Blood Sampling Stage}

The blood samples were taken through the jugular vein as much as $5 \mathrm{ml}$ each animal using venoject by quarantine officer by tightening the cow neck on the pen iron pole. The separation of the blood samples was done in a laboratory in the Agricultural Quarantine Station in Sumbawa and Pontianak. The serum 
which had been separated was divided into two micro tubes for the next examination of T3 and T4 and stored in freezer $\left(-8{ }^{\circ} \mathrm{C}\right.$ to $\left.-20^{\circ} \mathrm{C}\right)$ until the time of the examination.

\subsubsection{The Loading Stage}

After the preparation of the ship finished. The cows were loaded into the truck towards the harbor for the loading process. The cows in the ship were kept heads bound to a timber and given the green feed and drinking water ad libitum

\subsubsection{The Post Sea Transportation Stage}

After the ship docking, the cattle maintenance was done in Pontianak Animal Quarantine Installation for three days. Each cow was kept in a pen with the temperature 27 to $30{ }^{\circ} \mathrm{C}$ and placed in a row and given the green feed and drinking water ad libitum.

\subsubsection{The Blood Examination Stage}

The blood sample examination was done by using Elisa technique based on the procedures in T3 and T4 Elisa Kit (DRG $\left.{ }^{\circledR}\right)$.

\subsubsection{Statistical Analysis}

The results of ELISA were analyzed descriptively and statistically. The data were analyzed using one way Anova and calculate the average and standard deviation.

\section{Result and Discussion}

\subsection{Concentration of Triiodothyronine (T3) Blood Serum on Before and After Transportation}

The measurement of the T3 concentration of Balinese cow serum showed the fluctuate results. The T3 concentration declined when cattle were still in the Animal Quarantine Installation in Sumbawa (treated as the baseline in this study), increased during the cattle loading in the traditional vessel and began to decline $8 \mathrm{~h}$ after the ship docking. The results of T3 concentration of blood serum in Bali cows were presented with the average rate and standard deviation. The average T3 concentration in the baseline (pretransportation) at the Sumbawa Animal Quarantine Installation was $1.82 \pm 0.57 \mathrm{ng} / \mathrm{ml}$, loading the average concentration was $2.46 \pm 0.72 \mathrm{ng} / \mathrm{ml}$. The average T3 concentration after the transportation (docking) was $1.73 \pm 0.47 \mathrm{ng} / \mathrm{ml}$. The average T3 concentration in the Pontianak Animal Quarantine Installation was $1.91 \pm 0.45 \mathrm{ng} / \mathrm{ml}$ as presented in Table 1 .

Table 1. Levels of triiodothyronine (T3) hormone in female Bali breeding cattle

\begin{tabular}{lc}
\hline \multicolumn{1}{c}{ Period } & $\begin{array}{c}\text { Averages of Triiodothyronine (T3) } \\
\pm \text { Standard Deviations }\end{array}$ \\
\hline Baseline (in Sumbawa) & $1.82 \pm 0.57^{\mathrm{a}}$ \\
Loading & $2.46 \pm 0.72^{\mathrm{a}}$ \\
Docking & $1.73 \pm 0.47^{\mathrm{a}}$ \\
Post transportation (in Pontianak) & $1.91 \pm 0.45^{\mathrm{a}}$ \\
\hline
\end{tabular}

From Table 1, the results of measurement of the T3 serum concentration in Balinese cows showed that there was not significant difference $(p>0.05)$ between the T3 concentration of Bali cows before transportation / baseline in Sumbawa, loading, docking, and post transportation in Pontianak. Nonetheless, the fluctuate concentration of T3 could be caused by stress experienced by the cattle during the transportation. The transportation stress affected the process of the metabolism in the body, so that the T3 concentration increased. Meanwhile, the decreased T3 concentration during the ship docking was probably caused by the animal ability to adapt to the new environment. Besides, the body had returned to the normal basal metabolism after the cattle had received enough energy intake. The concentration of T3 and T4 enables the body lower the energy loss through the reduction of basal metabolism. According to [14] 
thyroid hormones increase the production of the heat and the use of oxygen use by the heart, liver, kidneys, and pancreas. The low levels of T3 reduce the speed of oxidation and synthesis of protein and fat. The T3 level can be used as the nutritional deficiency indicator [15]. The concentration of T3 is presented in Figure 1.

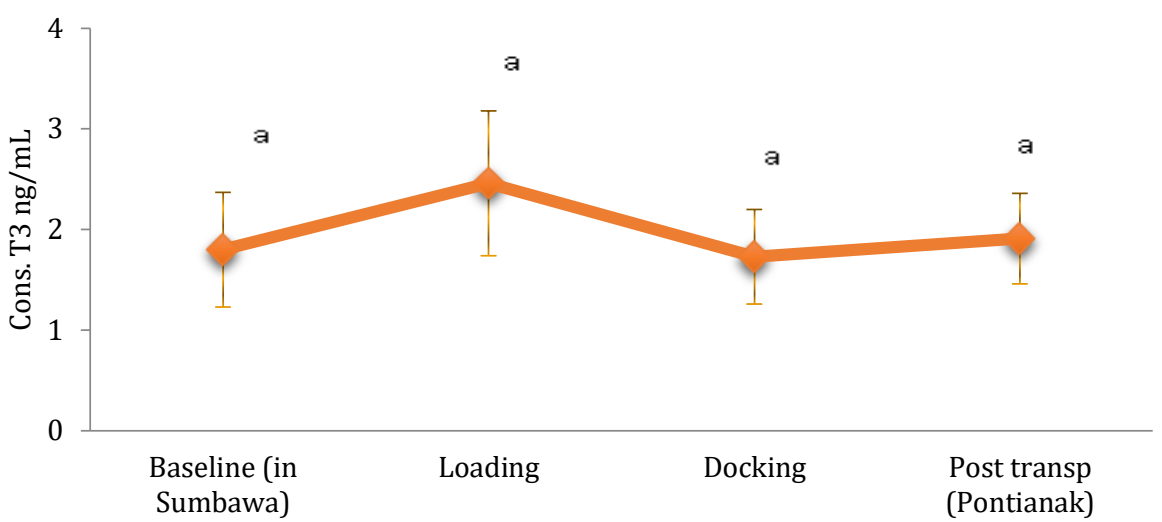

Fig. 1. Concentration of triiodothyronine (T3) serum in Balinesecow

Reference [16] reported that the normal concentration of T3 was $2.28 \mathrm{ng} / \mathrm{ml}$. The results of the measurement of T3 concentration increased during the cattle loading and decline during the ship docking. These fluctuate results could be caused by several factors. Firstly, in the process of transportation, the animals are often left unfed (fasting) and not given the drinking water, so that the body lacks energy resources. To fulfill the need of energy in the body, the changes in energy reserves occur in the body known as gluconeogenesis. In this condition, the concentration of the T3 hormone in the body increases. The concentration of this T3 hormone is closely related to the energy needs and nutritional balance in the body. The T3 hormone is generally used to increase the basal metabolism in the body, to produce more glucoses available for the cell, to stimulate the heart and nerves [15]. Therefore, the increased T3 hormone improve the basal metabolism in order to fulfill the needs of the energy in the body. After the body needs are fulfilled, the concentration of the T3 hormone in the body gradually declines. Secondly, when the animals are being transported the body tries to compensate by regulating the metabolism in order to increase the T3 concentration. Meanwhile the T3 concentration declined during the ship docking because the Balinese cow could adapt to the new environment and the body was back to the basal metabolism.

The T3 concentration continued to increase $8 \mathrm{~h}$ after the ship docking at Pontianak Animal Quarantine Installation. The increased T3 concentration could be caused by the blood sampling done at 14.45 WITA (Indonesia Eastern Time) with the environmental temperature of $30{ }^{\circ} \mathrm{C}$ and the humidity of $72 \%$, with 3 ${ }^{\circ} \mathrm{C}$ temperature increase, compared to the temperature of the docking time causing heat stress. Heat stress is the pressure caused by the temperature of the stall environment above the comfort zone of the body or the fluctuate temperature. Factors that are related to the heat stress and can affect the physiological condition are the temperature of the environment, relative humidity (\%) and energy radiation. The high environmental humidity can worsen the condition of the heat stress [17]. During the heat stress, a number of physiological responses and behaviors change because the adaptation to the heat stress requires the integration of some organs and systems. As a result of the thyroid effect, the T3 hormone increase and has an important function for the body metabolism process. The T3 response against heat stress is very slow and takes a few days to return to normal [18].

\subsection{Concentration of Thyroxine (T4) Blood Serum on Before and After Transportation}

Thyroxine or tetraiodothyronine (T4) hormone is a thyroid hormone found in the great number, but still in the form of inactive hormone [19]. The majority of the active metabolism hormones secreted by thyroid gland are the T4 hormone and the rest is T3. Nonetheless, at the end, all T4 hormone are change into the active T3 through the deiodinase process using enzyme 5'-deiodinase [20]. The results of the measurement of the $\mathrm{T} 4$ concentration in the Balinese cows are presented in Table 2. 
Table 2. The concentration of the thyroxine hormone (T4) in Balinese female cows

\begin{tabular}{lc}
\hline \multicolumn{1}{c}{ Period } & $\begin{array}{c}\text { Averages of Thyroxine (T4) } \\
\pm \text { Standard Deviations }\end{array}$ \\
\hline Baseline (in Sumbawa) & $24.49 \pm 6.47^{\mathrm{a}}$ \\
Loading & $27 \pm 7.28^{\mathrm{a}}$ \\
Docking & $20.56 \pm 11.90^{\mathrm{a}}$ \\
Post transportation (in Pontianak) & $22.82 \pm 11.65^{\mathrm{a}}$ \\
\hline
\end{tabular}

Based on the statistical analysis using the one-way Anova method there was not any differences $(p>0.05)$ between the T4 concentration in Balinese cows before the cattle transportation / baseline in Sumbawa, loading, docking and post transportation in Pontianak. The results of T4 concentration of blood serum in Bali cows were presented in the average rate and standard deviation. The average the T4 concentration before transportation was $24.49 \pm 6.47 \mu \mathrm{g} \cdot \mathrm{dL}^{-1}$, loading the average concentration was $27 \pm 7.28 \cdot \mathrm{dL}^{-1}$. The average T4 concentration after transportation (docking) was $20.56 \pm 11.90 \cdot \mathrm{dL}^{-1}$. The average T4 concentration $8 \mathrm{~h}$ after docking in Pontianak Animal Quarantine Installation was $22.82 \pm 11.65 \cdot \mathrm{dL}^{-1}$. T4 concentration are presented in Figure 2.

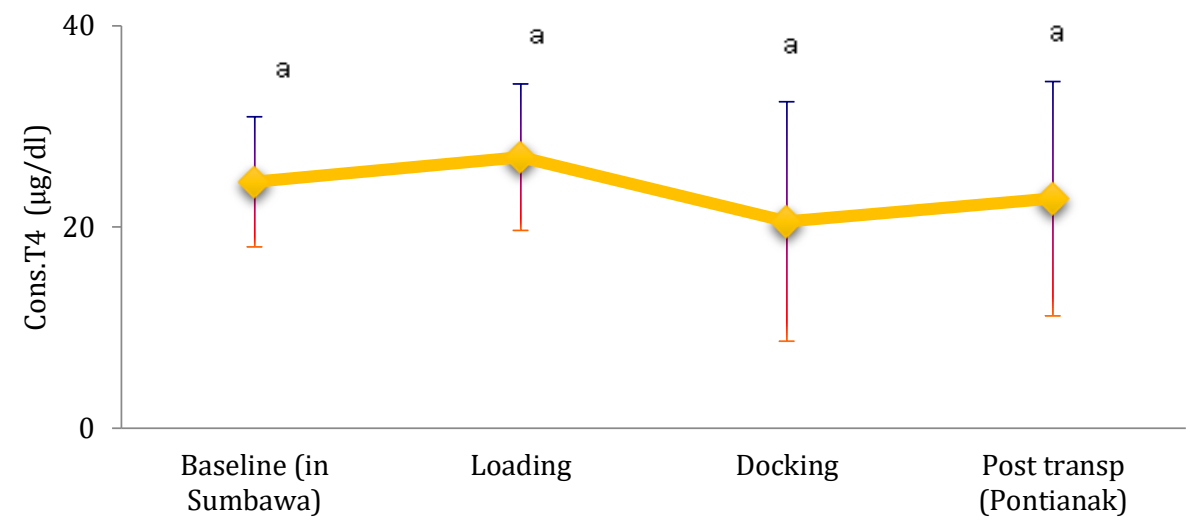

Fig. 2. The concentration of $\mathrm{T} 4$ serum in Balinese cows

The T4 concentration during the cattle loading was $27 \pm 7.28 \cdot \mathrm{dL}^{-1}$. The high $\mathrm{T} 4$ concentration during the cattle loading could be possibly caused by the transportation factor. The Balinese cows were transported to Dwikora Harbour in Sumbawa by using open trucks for $15 \mathrm{~min}$. At 03.00 WITA (Indonesia Central Time) the blood samples were taken as soon as the cattle had been unloaded from the trucks and the sampling site was in the first deck of the wooden ship with the crowded condition. This crowded condition could 
trigger the acute stress, as presented Figure 3. Reference [21] in their study, stated that the level of the thyroid hormone could change quickly in response to the stress.

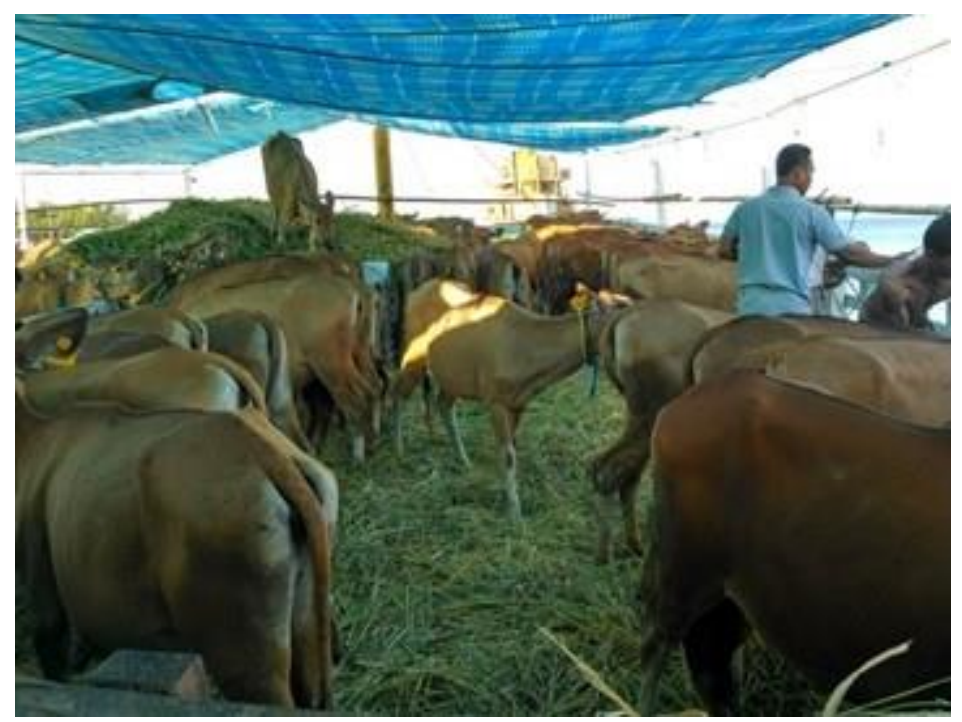

Fig. 3 Cattle placement in tradititional vessel

The concentration of T4 in Pontianak Animal Quarantine Installation was $22.82 \pm 11.6 \mu \mathrm{g} \cdot \mathrm{dL}^{-1}$ or the T3 concentration was higher than that in the docking time. This occurred allegedly because there were still free T4 hormones in the plasma, which were not converted into T3 [22]. Many factors simultaneously regulate the activity of the thyroid gland or the monodeiodinase. In addition to endogenous, environmental and climate factors, the nutrition has a major role in the activity of the thyroid gland and its concentration in the blood [15].

The concentrations of T3 and T4 have the same trends. The concentrations of T3 and T4 increased during the cattle loading period. These increased concentrations of T3 and T4 occurred because T4 played an important role in the transport and negative feedback in regulating the T3. Consequently, the increase in T4 was followed by the increase in T3 since many of T4 hormones were converted into T3 as the result of the cattle handling, density during the loading and restraining [23]. The concentrations of T3 and T4 are presented in Figure 4.

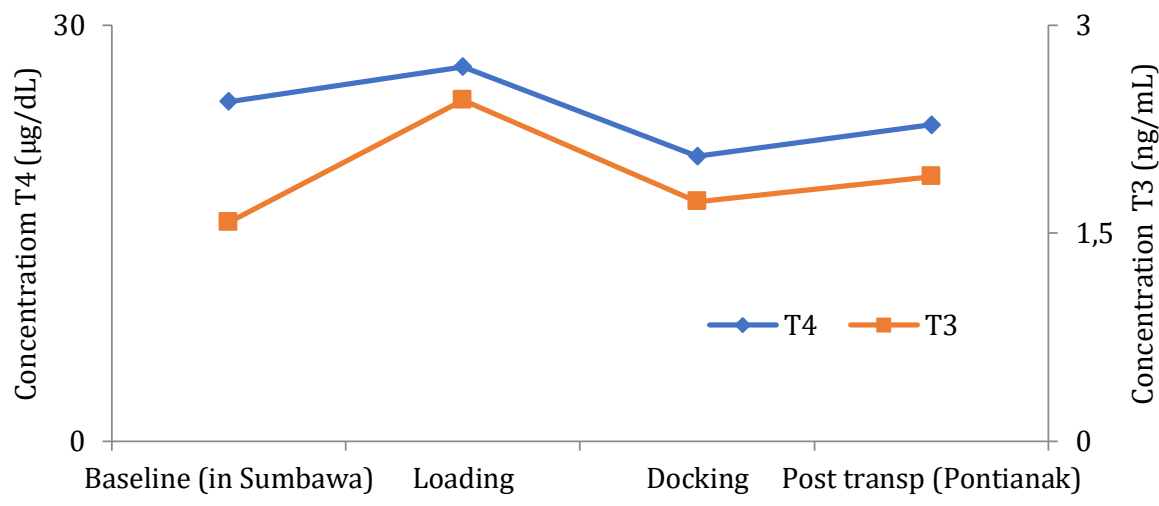

Fig. 4 The concentration of T3 and T4

Figure 4 showed the concentration of T3 and T4 increased at the stage of loading, declined at the docking period and increased back when the cattle were relocated in Pontianak Animal Quarantine Instalation. 


\section{Conclusions}

Triiodothyronine (T3) and thyroxine (T4) hormone levels can be used as an indicator of stress in studied Balicattle experiencing transportation stressalthough there were no differences found statistically. The result showed that there was a decline in triiodothyronine (T3) and thyroxine (T4) concentration, they increased during loading, decreased during docking, and decreased further when the livestock were at Pontianak Animal Quarantine Installation. It would be concluded that transportation affected the profile hormone of $\mathrm{T} 3$ and $\mathrm{T} 4$

\section{References}

1. Arifiantini, R.I., Wresdiyati, T., Retnani, E.F.: Pengujian morfologi spermatozoa sapi Bali (bossondaicus) menggunakan pewarnaan "Williams". [Sperm Morphology Assesment of Bali Bull Cattle Using "Williams" Stain]. J. Indon. Trop. Anim. Agric. 31(2), pp. 105-110 (2006). [in Bahasa Indonesia].

2. Phillips, C.J., Santurtun, E.: The welfare of livestock transported by ship. Vet. J. 196, 309-314 (2013).

3. Hambrecht, E., Eissen, J.J., Newman, D.J., Smits, C.H.M., den Hartog, L.A., den Verstegen M.W.A.: Negative effects od stress immediately before slaughter on pork quality are aggravated by suboptimal transport and lairage conditions. J. An. Sci. 83, 440-448 (2005).

4. Grandin, T.: Livestock handling and transport. 3rd Ed., pp. 44-45, 141-155, 161, 188. CAB International, England (2007).

5. Minka, N.S., Ayo, J.O.: Physiological espouses of food animals to road transportation stress. African Journal of Biotechnology 9(40), 6601-6613 (2010).

6. Kumar, S., Ajeet, K. dan Meena, K.: Effect of Heat Stress in Topical Livestock and Different Strategies for its Amelioration. Journal of Stress Phisiology and Biochemistry 7(1), 45-54 (2011).

7. Gariga, C., Hunter, R.R., Amat, C., Planas, J.M., Mitchell, M.A. and M. Moreto.: Heat stress increase apical glucose trasnport in the chicken jejunum. Am. J. Physio. Regul. Integr. Comp. Physiol. 290, R195-R201 (2006).

8. Hangalapura, B.N., Nieuwland, M.G., Buyse, J., Kemp, B., Parmentier, H.K.: Effect of duration of cold stress on plasma adrenal and thyroid hormone levels and immune response ini chickens line divergently selected for antibody respons. Poultry. Sci. 83, 1644-1649 (2004).

9. Fazio, E., Medica, P., Alberghina, P., Cavaleri, S., and Ferlazzo.: Effect of Long Distance Road Transport on Thryroid and Adrenal Function and Hematocrit Values in Limousin Cattle; Influence of Body Weight Decrease. Vet. Res. Commun. 29(8), 713-719 (2005).

10. Cunningham: Textbook of veterinary medicine. W.B Sauders; Philadelphia, Pennsylvania (2002).

11. Schultz-Altmann, A.G.T.: Engineering and design of vessels for sea transport of animals: The Australian design regulations for livestock carriers. Veterinaria Italiana 44, 247-258 (2008).

12. Norris, R.T.: Transport of animals by sea. Revue Scientifique Et Technique-Office International Des Epizooties 24, 673-681 (2005).

13. OIE (World Organization for Animal Health): Chapter 7.1. Introduction to the recomendations for Animal Walfare. Terrestrial Animal Health Code. pp. 291-305 (2012). 
14. Squires, E. J. Aplied Animal Endocrinology. pp. 16-34. CAB International Publishing Wallingford, Oxon 8 De, UK (2003).

15. Todini L.: Thyroid hormones in small ruminants: effects of endogenous, environmental, and nutritional factors. Anim 1, 997-1008 (2007).

16. Iveta, P., Seidel, H., Nagyo, Csilla, T., Kova, G.: Concentrations of Thyroid Hormones in Various Age Categories of Ruminants dan Swine. Acta Veterinaria (Beograd) 61, 489-503 (2011).

17. Marai, I.F.M., Haeeb, A.A.M. Buffalo's biological functions as affected by heat stress a review. Livestock Science 127, 89-109 (2010).

18. Silanikove, N.: Effects of heat stress on the welfare of extensively managed domestic ruminants. Livestock Production Science 67, 1-18 (2000).

19. Guyton, A.C., Hall, J.E.: Buku Ajar Fisiologi Kedokteran (Andrianto, P.S. Trans.). [Review of medical physiology].14th Edition, pp. 283-303. Penerbit Buku Kedokteran E.G.C, Jakarta. (2007).

20. Hernandez, A., Germain, D.L.: Thyroid hormone deiodinases: physiology andclinical disorders. Curr. Opin. Pediatr. 15, 416-420 (2003).

21. Friedman, Y., Bacchus, R., Raymond, R., Joffe, R.T., and Nobrega, J.N.: Acute stress increases thyroid hormone levels in rat brain. Biol. Psychiatry 45, 234-237 (1999).

22. Nazifi, S.: Studies on the relationship between thyroid hormones and some trace elements in the blood serum of Iranian fat-tailed sheep. Veterinary arhiv. 78(2), 159-165 (2008).

23. Cokram, M.S., Baxter, E.M., Smith, L.A., Bell, S., Howard, C.M., Prescott, R.J., Mitchell, M.A.: Effect of driver behaviour, driving events and road type on the stability and resting behaviour of sheep in transit. Animal Science 79, 165-176 (2004). 